\title{
Dopamine Modulates the Responsivity of Mediodorsal Thalamic Cells Recorded In Vitro
}

\author{
A. Lavin and A. A. Grace \\ Departments of Neuroscience and Psychiatry, Center for Neuroscience, University of Pittsburgh, \\ Pittsburgh, Pennsylvania 15260
}

\begin{abstract}
The mediodorsal thalamic nucleus (MD) receives convergent inputs from subcortical limbic structures that overlap with a dopaminergic (DA) innervation. In this study, we describe the effects of DA agonists on the basal and evoked electrophysiological activity of identified thalamic cells of rats recorded in vitro. Administration of the D1 agonist SFK $38393(10 \mu \mathrm{M})$ did not produce a clear effect on the physiological properties of the thalamic cells recorded. In contrast, bath administration of the D2 agonist quinpirole $(10 \mu \mathrm{M})$ resulted in an enhancement of membrane excitability, facilitation of the occurrence of lowthreshold spikes (LTSs), and changes in the resting membrane
\end{abstract}

potential of the thalamic cells tested. The quinpirole-mediated responses were reversed by administration of the D2 antagonist haloperidol. Results from experiments performed with different $\left[\mathrm{K}^{+}\right]$and $\mathrm{K}^{+}$channel blockers suggest that the effects of quinpirole are mediated at least in part by changes in $\mathrm{K}^{+}$ conductances. The results from this study suggest that DA can modulate the excitability of thalamic cells and in turn may influence the way that the thalamocortical system integrates information.

Key words: thalamus; dopamine; low-threshold spikes; $\mathrm{K}^{+}$ conductances; D1 agonist; D2 agonist
The mediodorsal thalamic nucleus (MD) is a site through which the majority of limbic structures influence cortical processing. This nucleus receives input from dopamine-rich regions of the limbic system, including projections from the nucleus accumbens and the ventral pallidum (Haber et al., 1985; Zahm et al., 1987; Groenewegen, 1988, Groenewegen and Berendse, 1994; Lavin and Grace, 1994). Anatomical studies have described a dopaminergic innervation of the MD and paraventricular nuclei (PV) of the thalamus as well. The dopaminergic innervation of the thalamus was first described in 1974 (Lindvall and Björklund, 1974) and is believed to arise from the A11 and A13 dopaminergic cell groups that represent the hypothalamic dopamine neurons (Füxe, 1965). Subsequent studies using autoradiographic techniques showed the presence of anterogradely labeled axons ascending from the ventral tegmental area (VTA) and terminating in the medial part of the mediodorsal thalamic nuclei (Beckstead et al., 1979). Furthermore, injections of the retrograde tracer HRPwheat germ agglutinin (WGA) into the medial and lateral MD labeled neurons in large numbers within the midline VTA (Cornwall and Phillipson, 1988). This VTA-MD projection was confirmed to be at least partially dopaminergic in studies using combined retrograde and anterograde tracers (Groenewegen, 1988) and immunohistochemical staining for tyrosine hydroxylase $(\mathrm{TH})$.

Although the dopaminergic innervation of the thalamus is not as extensive as that of striatal regions, several studies have re-

\footnotetext{
Received Aug. 12, 1998; revised Sept. 18, 1998; accepted Sept. 22, 1998.

This work was supported by a fellowship from the National Alliance for Research on Schizophrenia and Depression (A.L.) and United States Public Health Service Grants MH01055, MH57440, and MH45156. We thank Mr. Brian Lowry for providing the computer program for data analysis (Neuroscope). We also thank Dr. H. Moore for her advice on the statistical analysis and for critical comments and useful discussions.

Correspondence should be addressed to Dr. Antonieta Lavin, Department of Neuroscience, 446 Crawford Hall, University of Pittsburgh, Pittsburgh, PA 15260. Copyright (C) 1998 Society for Neuroscience 0270-6474/98/1810566-13\$05.00/0
}

vealed the presence of D1, D2, D4, and D5 subtypes of DA receptors in the MD thalamic region (Fields et al., 1977; Boyson et al., 1986; Dawson et al., 1986; Camps et al., 1989; Mansour et al., 1990, 1992; Young and Wilcox, 1991; Huang et al., 1992; Janowski et al., 1992; Levant et al., 1992; Machida et al., 1992; Civelli et al., 1993; Hall et al., 1996; Sedvall and Farde, 1996). Furthermore, neurochemical studies suggest that although the density of DA fibers in the thalamus is moderate, this monoamine has a widespread distribution in both the human and rodent thalamus (Lindvall and Björklund, 1974; Oke et al., 1980, 1983; Santiago et al., 1989; Aizawa et al., 1991; Young and Wilcox, 1991).

Several studies suggested that the MD may have an involvement in schizophrenia (Carlsson and Carlsson, 1990; Pakkenberg, 1990; Berendse and Groenewegen, 1991; Andreasen et al., 1995; Young et al., 1995; Blennow et al., 1996; Buchsbaum et al., 1996; Heckers, 1997); however, few physiological studies have been performed to assess the possible functional significance of a dopaminergic innervation in this region. In the present study, we examined the effects of DA agonists on the basal and evoked activity of neurons located in the MD and PV nuclei of the rat thalamus recorded in vitro.

\section{MATERIALS AND METHODS}

Intracellular current-clamp recordings were performed from neurons within sagittal slices of the MD and PV nuclei of the thalamus of adult rats (200-250 gm; Zivic Miller Labs). All procedures were performed in accordance with the Guide for the Care and Use of Laboratory Animals published by the United States Public Health Service; the experimental protocol was approved by the University of Pittsburgh Institutional Animal Care and Use Committee. The rats were deeply anesthetized with chloral hydrate $(400 \mathrm{mg} / \mathrm{kg}$, i.p.) before transcardial perfusion with ice-cold physiological saline (124 mM NaCl, $5 \mathrm{~mm} \mathrm{KCl}, 1.2 \mathrm{~mm} \mathrm{KH}_{2} \mathrm{PO}_{4}$, $2.4 \mathrm{mM} \mathrm{CaCl}_{2}, 1.3 \mathrm{~mm} \mathrm{MgSO}_{4}, 26 \mathrm{~mm} \mathrm{NaHCO}_{3}$, and $10 \mathrm{~mm}$ glucose, and saturated with $95 \% \mathrm{O}_{2} \% / 5 \% \mathrm{CO}_{2}$; an additional $115 \mathrm{~mm}$ sucrose was added to fresh standard superfusate for use with perfusion). The brain 
was then removed rapidly, and 4-mm-thick sagittal blocks containing the MD and PV were made using a Rat Brain Matrix (RBM $4000 \mathrm{~S}$ ). The blocks were placed on a Vibratome (Pelco, Series 1000) and sectioned into $400-\mu \mathrm{m}$-thick slices in ice-cold physiological saline. The slices were then incubated at room temperature in continuously oxygenated physiological saline for at least $1 \mathrm{hr}$ before recording.

In vitro electrophysiological recording procedure. Recordings were performed using a submersion-type recording chamber. The chamber was superfused with oxygenated physiological saline maintained at $33-35^{\circ} \mathrm{C}$ at a flow rate of 1-2 $\mathrm{ml} / \mathrm{min}$ (Llinás and Sugimori, 1980) controlled by a peristaltic pump (Haake-Büchler, model MCP 2500). The time required for a complete exchange of media within the chamber was $3 \mathrm{~min}$. Sharp electrodes were constructed from $1 \mathrm{~mm}$ outside diameter Omegadot (WPI, New Haven, CT) borosilicate glass tubing using a horizontal puller (Flaming-Brown P-80/PC). The electrodes were filled with $3.0 \mathrm{M}$ $\mathrm{K}^{+}$acetate and had resistances of 55-90 M $\Omega$ measured in situ. The location of the recording site was determined by visual inspection of the placement of the recording electrode using a stereomicroscope (Nikon SMZ-2B), with the MD and PV divisions identified using a rat brain stereotaxic atlas (Paxinos and Watson, 1986). The electrodes were connected to the head stage component of a NeuroData intracellular amplifier (IR-183). Current was injected into neurons through an active bridge circuit integral to the amplifier, with the amplitude of the current injected and the electrode voltage monitored on an oscilloscope (Kikusui COS5020-ST). Data were digitized and stored on VHS videotapes for subsequent off-line analysis. The analysis was performed using custom software (Neuroscope) running on a windows-based microcomputer. The input resistance, spike threshold, current threshold, resting membrane potential (RMP), spike amplitude, and amplitude of the evoked lowthreshold spikes (LTSs) were compared in neurons in control conditions and after drug treatment. The input resistance was measured by injecting a series of hyperpolarizing constant current pulses of increasing amplitude (150 msec duration) into the cell and measuring the resultant changes in membrane potential. To assess activation and inactivation potentials of the LTSs, a series of hyperpolarizing pulses (150 msec duration) was injected into the cell until a clear LTS was evoked, and then constant hyperpolarizing or depolarizing current was injected into the cells to alter the steady-state membrane potential. The first derivative of the LTS was obtained using the Neuroscope program, and the amplitude of the derivative was plotted against the value of the membrane potential at which it was evoked. All data are shown as mean \pm SD.

Pharmacological treatment. All drugs were applied by first dissolving them in physiological saline. After obtaining stable baseline data and recording the responses to intracellular current injection, the perfusion lines were switched from control physiological saline to the drugcontaining media while maintaining stable perfusion pressure and fluid volume via the peristaltic pump delivery system. The drugs used were quinpirole $(10 \mu \mathrm{M})$, SKF $38393(10 \mu \mathrm{M})$, SCH $23390(10 \mu \mathrm{M}), \mathrm{Co}^{2+}(2.4$ $\mathrm{mM}), \mathrm{Cs}^{+}(2 \mathrm{mM})$, haloperidol $(10 \mu \mathrm{M})$, and clozapine $(10 \mu \mathrm{M})$.

Statistics. The following tests were used: Student's $t$ test, ANCOVA, and McNemar comparison test

\section{RESULTS}

The results presented here were obtained from 63 neurons recorded in vitro in the MD that exhibited stable intracellular impalements (duration $=30 \mathrm{~min}$ to $3 \mathrm{hr}$ ). Stability was defined as exhibiting resting membrane potentials more negative than -55 $\mathrm{mV}$ and spike action potentials with amplitudes of $55 \mathrm{mV}$ or greater. The effects of bath application of the DA D1 agonist SKF 38393 and the DA D2 agonist quinpirole on passive membrane properties were examined on 11 and 40 MD neurons, respectively.

\section{Basic morphological and physiological properties of thalamic cells recorded in vitro}

The morphology of the thalamic cells recorded was examined by intracellular staining with the dye Lucifer yellow. Consistent with other reports, the cells exhibited somata with diameters ranging between 20 and $40 \mu \mathrm{m}$ that were round or fusiform in shape. Dense clusters of dendrites emanated from the poles of the soma (Fig. 1). All of the cells stained in the present study exhibited similar morphological characteristics $(n=4)$ that were consistent with the primary class of relay cells in the MD.

Intracellular recordings in vivo and in vitro have shown that thalamic neurons have two basic patterns of firing, depending on the level of depolarization or hyperpolarization of the membrane potential: tonic irregular spiking (approximately $-58 \mathrm{mV}$ ) and rhythmic burst firing (approximately $-70 \mathrm{mV}$ ) (for review, see Steriade and Deschênes, 1984; Steriade and Llinás, 1988; McCormick, 1992). As reported by others, the burst firing recorded in MD thalamic cells was composed of an LTS that triggers the discharge of 2-10 spikes (Fig. 2).

\section{Effects of D1 agonist on MD cell physiology}

Bath-applied SKF $38393(10 \mu \mathrm{M})$ did not produce changes in the resting membrane potential, input resistance, or spike threshold in 10 of 11 cells tested (Table 1). A slight but nonsignificant decrease $(27 \%)$ in the threshold current required to evoke spike firing was observed after administration of the D1 agonist.

To assess the specificity of DA agonist effects on thalamic cells, the D1 selective antagonist SCH $23390(10 \mu \mathrm{M})$ and the preferential D2 antagonist haloperidol $(13 \mu \mathrm{M})$ were tested by bath application. The D1 antagonist SCH 23390 (four cells) and the mixed D1/D2 antagonist haloperidol (two cells) were tested after 5 min of SKF 38393 administration. Neither antagonist altered the response to SKF 38393; however, haloperidol appeared to produce a depolarization of the membrane potential (RMP control $=-67.5 \pm 6.5$; SKF $38393=66.1 \pm 1.1$; haloperidol $=-57.4 \pm 4.5$ ) without altering the input resistance.

\section{Effects of D2 agonist on MD cell physiology}

Resting membrane potential and input resistance

The pre-drug fluctuations in RMP typically did not exceed \pm $3 \mathrm{mV}$; therefore, post-drug changes in RMP greater than $\pm 5 \mathrm{mV}$ were operationally defined as different from baseline. When the D2 agonist quinpirole $(10 \mu \mathrm{M})$ was applied, 19 of $37(51.3 \%)$ of the neurons tested exhibited a $5.9 \pm 4.9 \mathrm{mV}$ hyperpolarization of their membrane potential $\left[t_{(36)}=-5.50 ; p<0.00003\right.$ ] (Table 2, Figs. 3,4$)$. In contrast, 6 of 37 cells $(19 \%)$ exhibited a significant depolarization of the resting membrane potential measured $5 \mathrm{~min}$ after administration of the $\mathrm{D} 2$ agonist $\left[3.4 \pm 0.7 \mathrm{mV} ; t_{(36)}=2.57\right.$; $p<0.006$ ] (Table 2, Fig. 4). Finally, in $29.7 \%$ of the cells tested (11 of 37), quinpirole did not produce changes in the average resting membrane potential.

Quinpirole did not affect input resistance in the cells that exhibited depolarization of the resting membrane potential or hyperpolarization of the membrane potential, or those that did not show changes in membrane potential after drug application (Fig. 2). Furthermore, the quinpirole effect on membrane potential did not correlate with changes in input resistance.

Because other drug-induced changes may be secondary to the changes in RMP, we determined whether the effects of quinpirole on spike threshold, threshold current, and input resistance were correlated with the effects on RMP. The factors used in subsequent ANOVAs of these variables were based on this correlational analysis (see below).

\section{Spike threshold}

Because of the trend for effects on membrane potential and given the fact that spike threshold can depend on membrane potential, the possibility was tested that quinpirole would have an effect on spike threshold that was dependent on its effect on membrane potential. Therefore, the effects of quinpirole on spike threshold 


\section{$\overline{50}$ um}

Figure 1. Photomicrograph of a neuron recorded in the MD thalamus and labeled by intracellular injection with Lucifer yellow. This neuron had a round soma that measured $30 \mu \mathrm{m}$ in diameter and exhibited a dense array of dendritic processes.

were analyzed with a repeated measures ANCOVA using the effect of quinpirole on membrane potential as a covariate. This analysis revealed a significant positive correlation between the effect of quinpirole on membrane potential and spike threshold $(r=0.73 ; p<0.01)$, confirming that the effect of quinpirole on spike threshold could be predicted in large part by its effects on membrane potential. When this effect was accounted for, the effect of quinpirole on spike threshold was not significant $(r$ $(1,1,15)=2.4 ; p=0.15)$. When the cells were separated according to the quinpirole effects on RMP, the D2 agonist was found to produce an increase in the spike threshold only in the cells that also were depolarized by quinpirole (Table 2). In contrast, in cells in which quinpirole administration resulted in either a hyperpolarization or no change in RMP, it also failed to significantly alter spike threshold.

\section{Afterhyperpolarization}

In several cases ( $n=5$ of 16) (Fig. 5), quinpirole administration was observed to increase the amplitude and duration of the post-spike afterhyperpolarization (AHP) (amplitude control, $7.9 \pm 2.3 \mathrm{mV}$; amplitude quinpirole, $13.1 \pm 6.5 \mathrm{mV} ; p<0.08$; 

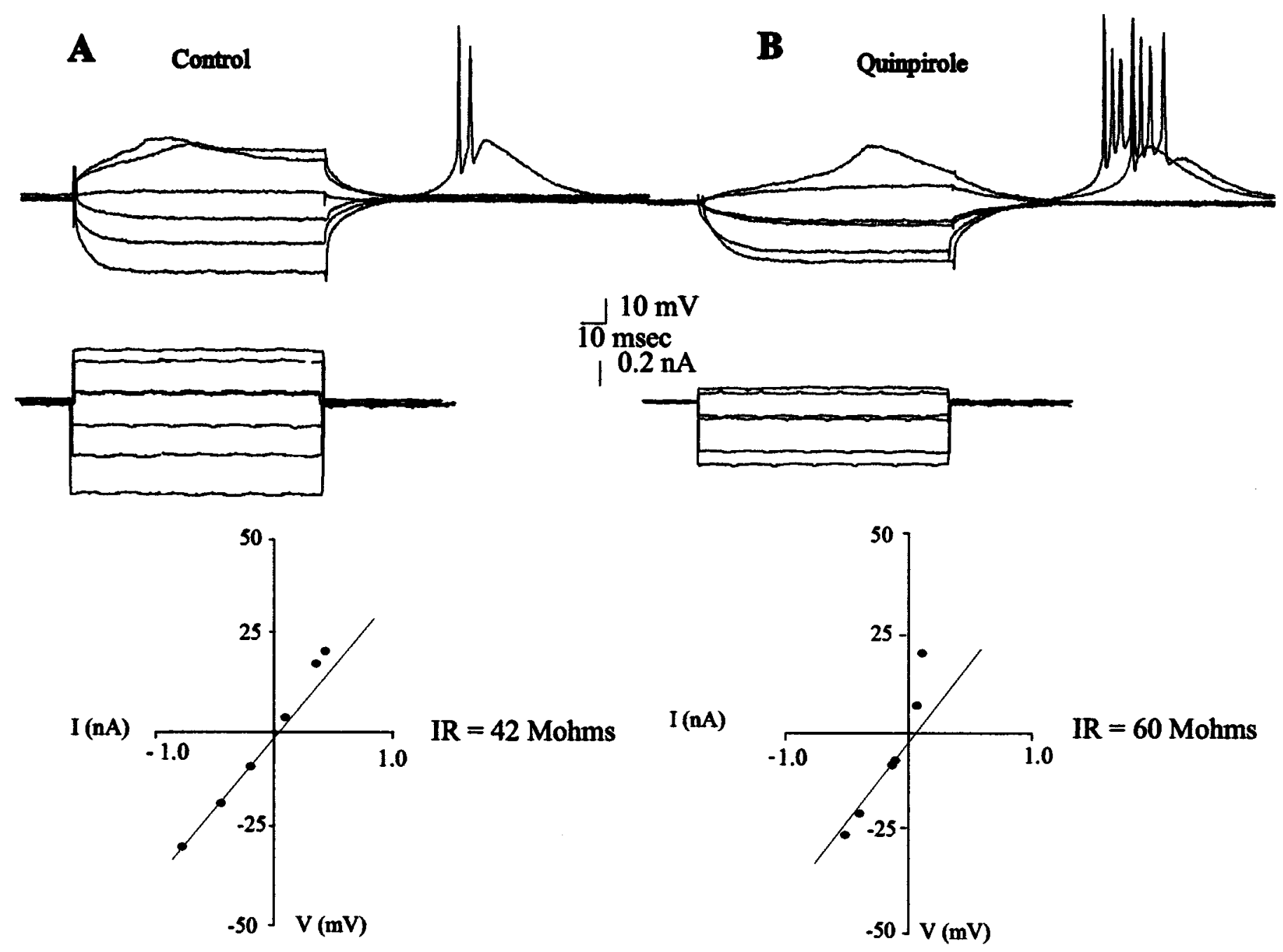

Figure 2. Effects of quinpirole on the input resistance and facilitation of LTSs. The input resistance $(I R)$ of this neuron recorded before $(A)$ and after $(B)$ administration of quinpirole $(10 \mu \mathrm{M})$ was determined by examining the membrane voltage deflections (top traces) produced in response to injections of current (bottom trace) and calculating the input resistance from the $I-V$ regression line (bottom graph). After quinpirole administration, a facilitation of the LTS is observed during injection of depolarizing currents pulses. Moreover, an increase in membrane excitability is revealed, with excitability defined as a reduction in the amount of current required to produce a given level of depolarization of the membrane potential. In the $I-V$ curve, $0 \mathrm{mV}$ corresponds to the RMP.

Table 1. Effect of D1 agonist SKF 38393 and D1 antagonist SCH 23390 on basic membrane properties of thalamic cells

\begin{tabular}{|c|c|c|c|c|c|}
\hline & \multicolumn{2}{|c|}{ Effects of SKF $38393(n=11)$} & \multicolumn{3}{|c|}{ Effects of SCH $23390(n=4)$} \\
\hline & Control & SKF 38393 & Control & SKF 38393 & SCH 23390 \\
\hline Membrane potential $(\mathrm{mV})$ & $68.3 \pm 8.7$ & $68.7 \pm 9.8$ & $67.6 \pm 12.6$ & $66.9 \pm 13.7$ & $62.7 \pm 15.4$ \\
\hline Input resistance $(\mathrm{M} \Omega)$ & $45.5 \pm 19.0$ & $39.3 \pm 14.4$ & $58.2 \pm 21.4$ & $42.2 \pm 12.5$ & $56.2 \pm 15.0$ \\
\hline Spike threshold (mV) & $52.0 \pm 8.1$ & $46.7 \pm 5.7$ & $46.9 \pm 8.4$ & $44.7 \pm 5.3$ & $38.6 \pm 7.0$ \\
\hline Current threshold (nA) & $0.44 \pm 0.23$ & $0.32 \pm 0.14$ & $0.55 \pm 0.15$ & $0.28 \pm 0.17$ & $0.42 \pm 0.22$ \\
\hline LTS-evoked (rebound) & $3 / 9$ & $4 / 11$ & $2 / 4$ & $2 / 4$ & \\
\hline
\end{tabular}

duration control, $12.9 \pm 6.1 \mathrm{msec}$; duration quinpirole, $28.1 \pm 9.5$ msec).

\section{Current-evoked spike discharge}

The effects of quinpirole on RMP did not correlate with its effects on the threshold current required to trigger spike discharge; therefore, data from all cells were analyzed as a single group.
Quinpirole administration was found to cause a significant decrease in threshold current in the cells tested $\left[t_{(29)}=4.14 ; p<\right.$ $0.001]$.

\section{Low-threshold spikes}

Before drug administration, 8 of $31(25.8 \%)$ of the cells tested exhibited an LTS in response to spike threshold levels of mem- 
Table 2. Effects of D2 agonist quinpirole and D2 antagonist haloperidol on basic membrane properties of thalamic cells

\begin{tabular}{|c|c|c|c|c|c|c|}
\hline \multirow[b]{3}{*}{ Membrane potential $(\mathrm{mV})$} & \multicolumn{2}{|c|}{ Hyperpolarize $(n=19)$} & \multicolumn{2}{|c|}{ Depolarize $(n=7)$} & \multicolumn{2}{|c|}{ No changes $(n=11)$} \\
\hline & Control & Quinpirole & Control & Quinpirole & Control & Quinpirole \\
\hline & $65.5 \pm 4.7$ & $71.7 \pm 6.7^{*}$ & $67.8 \pm 10.9$ & $64.4 \pm 12.0^{* *}$ & $63.0 \pm 5.4$ & $63.7 \pm 5.3$ \\
\hline Changes in membrane potential $(\mathrm{mV})$ & & $5.9 \pm 4.9$ & & $3.4 \pm 0.7$ & & $0.7 \pm 2.7$ \\
\hline Input resistance $(\mathrm{M} \Omega)$ & $33.8 \pm 13.4$ & $41.3 \pm 19.1$ & $32.4 \pm 21.0$ & $47.2 \pm 18.4$ & $39.3 \pm 18.1$ & $37.3 \pm 20.5$ \\
\hline Spike threshold $(\mathrm{mV})$ & $48.5 \pm 4.3$ & $51.1 \pm 11.8$ & $52.4 \pm 7.2$ & $45.5 \pm 8.6^{* * *}$ & $49.0 \pm 7.2$ & $41.9 \pm 6.3$ \\
\hline Current threshold (nA) & $0.44 \pm 0.26$ & $0.27 \pm 0.17$ & $0.31 \pm 0.11$ & $0.08 \pm 0.05^{* * * *}$ & $0.44 \pm 0.30$ & $0.25 \pm 0.35$ \\
\hline LTS-evoked (rebound) & $2 / 19$ & $10 / 19^{+}$ & $4 / 7$ & $1 / 7$ & $2 / 11$ & $4 / 11$ \\
\hline
\end{tabular}

$* p<0.0031 ; t=-5.50$.

$* * p<0.0006 ; t=2.57$.

$* * * p<0.04 ; t=3.27$.

$* * * * p<0.005 ; t=5.38$.

${ }^{+} p<0.0005$ (plotting together all controls vs all LTSs).

A Control B Quinpirole $\quad$ C Quinpirole
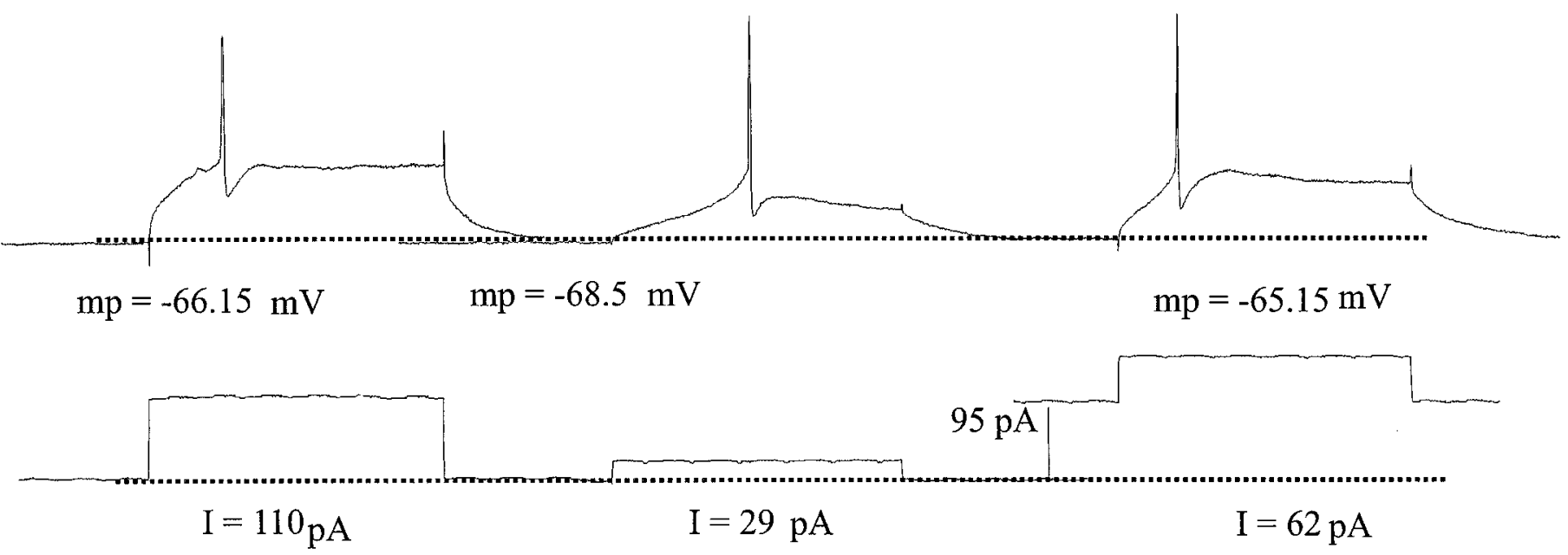

$\underset{10 \mathrm{msec}}{-10 \mathrm{mV}}$

Figure 3. The facilitation of the LTS observed after quinpirole administration persisted after the membrane potential of the cell was adjusted by current injection to the original pre-drug control values. $A$, A cell recorded during control conditions exhibits an evoked action potential in response to depolarizing current injection ( $\mathrm{RMP}=-66.15) . B$, Quinpirole administration caused a hyperpolarization of the membrane of this cell by $2.4 \mathrm{mV}$, in addition to facilitating the expression of the LTS. $C$, After depolarizing the membrane potential of this cell back to the original pre-drug RMP by current injection, the LTS could still be evoked by small amplitudes of membrane depolarization. It should be noted that LTSs were not evoked at this RMP in the absence of quinpirole administration. $m p$, Membrane potential.

brane depolarization. However, after $10 \mu \mathrm{M}$ quinpirole administration, $48.8 \%$ (15 of 31) of these cells exhibited threshold current-evoked LTSs (Table 2, Figs. 2-4). Using a McNemar test that compares the frequency of LTSs before and after quinpirole, the probability of evoking an LTS after quinpirole administration was found to be significantly greater than during pre-drug conditions $(p<0.0005)$. The effects of quinpirole administration on the depolarization-dependent inactivation curve of the LTS also was analyzed. For membrane potential values between -55 and $-70 \mathrm{mV}$, quinpirole produced a small shift of the curve to the right, indicating that quinpirole administration caused a relative facilitation of the evoked LTSs at these membrane potential values. However, between -70 and $-82 \mathrm{mV}$, quinpirole caused the curve to shift to the left (Fig. 6). In fact, at membrane potential values between -55 and $-65 \mathrm{mV}$, the average rate of change in the amplitude of the LTS was larger after quinpirole administration (55-60 mV: control, $0.023 \mathrm{mV} / \mathrm{sec}$; quinpirole, $0.0580 \mathrm{mV} / \mathrm{sec}$; 61-65 mV: control, $0.0342 \mathrm{mV} / \mathrm{sec}$; quinpirole, $0.0593 \mathrm{mV} / \mathrm{sec}$, respectively). In three of the above cells that exhibited LTSs after quinpirole, the cells also began to exhibit spontaneous spike discharge (Fig. 7). In the cells that were hyperpolarized by quinpirole administration, the current threshold required to evoke an LTS was decreased; however, this decrease did not reach statistical significance. Nonetheless, in the cells depolarized by quinpirole administration, there was a significant decrease in the current threshold required to evoke the LTSs $(p<0.0005 ; t=5.38)$. In 16 of 29 cases $(55 \%)$, the latency of the LTS or spike after quinpirole was increased significantly $(p<$ 

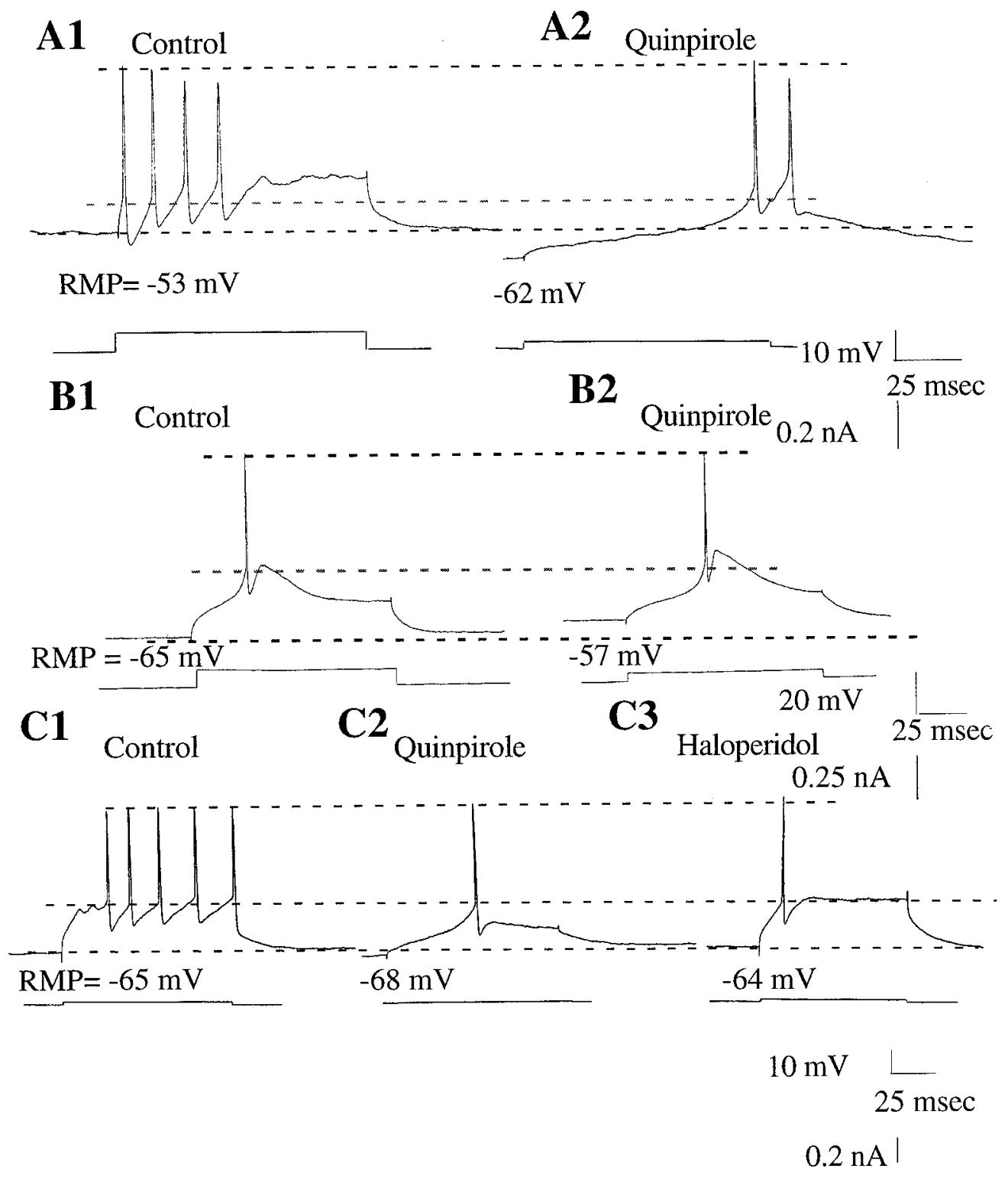

Figure 4. Quinpirole administration altered the excitability and spike discharge in half of the MD cells tested. $A 1$, Spikes evoked by current injection during the control period. A2, Quinpirole administration $(10 \mu \mathrm{M})$ hyperpolarized the membrane potential of this cell, facilitated the expression of the LTS, and increased cell excitability. $B 1$, An LTS evoked by current injection during the control period. B2, Quinpirole administration (10 $\mu \mathrm{M})$ caused a depolarization of the membrane potential of this cell without altering the LTS. C1, A tonic pattern of firing was evoked in this neuron by current injection during the control period. $C 2$, Administration of quinpirole $(10 \mu \mathrm{M})$ caused a small hyperpolarization of the membrane potential of the cell, facilitated expression of the LTS, and markedly increased cell excitability. C3, Haloperidol administration $(13 \mu \mathrm{M})$ reversed the quinpiroleinduced hyperpolarization of this cell to control values. The current-evoked action potential now occurred independent of a prominent LTS. The cell excitability also returned to control levels. The bottom traces in each panel indicate the amplitude of the current injected. The bottom dashed line indicates the control RMP, the middle dashed line indicates the spike threshold during the control period, and the top dashed line represents the peak amplitude of the action potential.
0.00007; $t=-6.8$ ). In addition to the responses produced by administration of $10 \mu \mathrm{M}$ quinpirole, the effects of quinpirole administered at doses of 5 and $50 \mu \mathrm{M}$ were tested in three cells. At a dose of $5 \mu \mathrm{M}$, quinpirole had variable effects in that it caused the appearance of LTSs in 1 of 3 cells, whereas at a dose of $50 \mu \mathrm{M}$ quinpirole produced a hyperpolarization of the membrane potential and evoked LTSs in all of the cases tested

\section{Effects of antipsychotic drug administration on quinpirole-induced responses}

Administration of haloperidol was found to reverse the primary responses produced by quinpirole in four of five cells tested. In this group, haloperidol $(13 \mu \mathrm{M})$ reversed the membrane hyperpolarization caused by quinpirole (Table 3, Fig. 4). Haloperidol administration also restored spike threshold to baseline levels and caused the neuron to respond with tonic spike discharge instead of LTSs when current was injected. However, haloperidol did not reverse the small decrease in the threshold current required for spike generation; instead it caused a further significant decrease in this value (control $=0.31 \pm 0.02 \mathrm{nA}$; quinpirole $=0.27 \pm 0.20$
$\mathrm{nA}$; haloperidol $=0.09 \pm 0.09 \mathrm{nA} ; p<0.03)$. In cells in which haloperidol was applied alone (i.e., without quinpirole pretreatment), it did not alter any of the basic electrophysiological properties tested (data not shown).

The responses to bath application of the atypical antipsychotic drug clozapine $(10 \mu \mathrm{M})$ were also examined. In the three cases tested, clozapine was found to reverse the quinpirole-induced membrane hyperpolarization (RMP control, $-67.8 \pm 0.3 \mathrm{mV}$; quinpirole, $-72.3 \pm 11.5 \mathrm{mV}$; clozapine, $-61.2 \pm 6.5 \mathrm{mV}$ ). However, in contrast to haloperidol administration, clozapine failed to reverse the quinpirole-mediated increase in spike threshold, and instead caused a further increase in this parameter (control, $-67.6 \pm 15.56 \mathrm{mV}$; quinpirole, $-52.4 \pm 22.7 \mathrm{mV}$; clozapine, $-46.1 \pm 5.4 \mathrm{mV})$.

\section{Possible membrane conductance changes underlying quinpirole-mediated responses}

To determine the mechanism through which quinpirole modulates the excitability of MD neurons, experiments were performed to assess the membrane conductance changes that may 


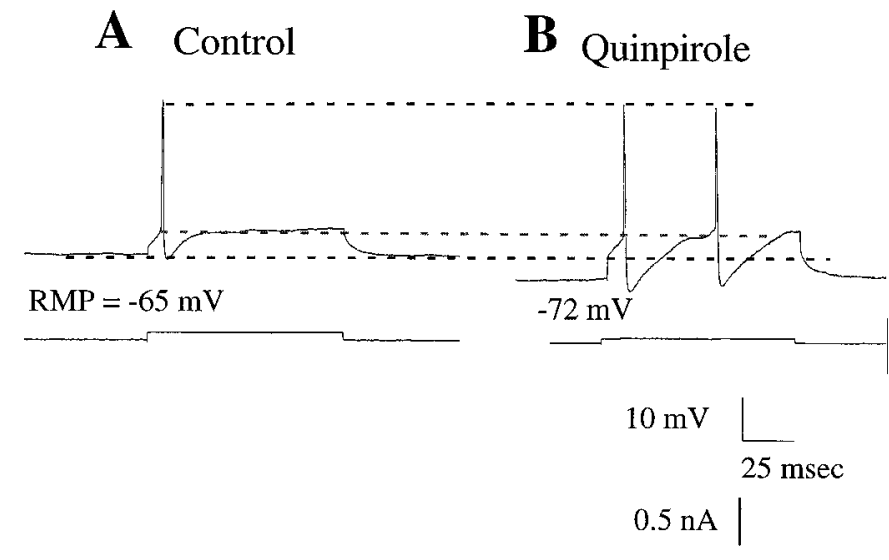

Figure 5. Effects of quinpirole administration on spike AHPs. In several cases quinpirole administration caused the evoked spikes to have longer duration and larger amplitude spike afterhyperpolarizations than in the control conditions. $A$, An action potential evoked during the control period exhibited a small amplitude and short duration AHP. B, After quinpirole administration $(10 \mu \mathrm{M})$, the AHP of this cell was increased by $67 \%$ in amplitude and $125 \%$ in duration. A quinpirole-induced increase in excitability was also noted.

have contributed to this response. Our initial focus was on the potassium conductances, given the evidence that DA acting on D2-type receptors in striatal and substantia nigra zona compacta cells activates $\mathrm{K}^{+}$conductances (Uchimura et al., 1986; Lacey et al., 1987, 1988; Freedman and Weight, 1988, 1989; Surmeier and Kitai, 1993; Liu et al., 1994; Seeman and Van Tol, 1994; Greif et al., 1995). To assess whether $\mathrm{K}^{+}$conductances play a role in the responses observed after D2 agonist administration, we retested these responses using different concentrations of $\mathrm{K}^{+}$in the superfusion fluid (i.e., 2.5, 6.5, and $10 \mathrm{~mm}$ ). Cell responses were analyzed separately depending on whether quinpirole caused a facilitation of the LTS. For cells in which the LTS was facilitated by quinpirole, the reversal potentials for the quinpirole-mediated responses were as follows: in $2.5 \mathrm{mM} \mathrm{K}^{+}=-89.7 \pm 7.0 \mathrm{mV}(n=$
$3)$; in $6.5 \mathrm{mM} \mathrm{K} \mathrm{K}^{+}=-74.5 \pm 8.2 \mathrm{mV}(n=13)$, and in $10 \mathrm{~mm}$ $\mathrm{K}^{+}=-66.4 \pm 11.2 \mathrm{mV}(n=3)$. The slope of the regression line for this group was calculated to be $25.5 \mathrm{mV} / \log$ unit $\mathrm{K}^{+}$concentration (Fig. 8). Furthermore, administration of the potassium channel blocker cesium $\left(\mathrm{Cs}^{+} ; 2 \mathrm{~mm}\right)$ was found to reverse the quinpirole-induced hyperpolarization of the membrane potential (RMP control, $-74.3 \pm 5.8 \mathrm{mV}$; quinpirole, $-84.5 \pm 2.1 \mathrm{mV}$; $\left.\mathrm{Cs}^{+},-70.4 \pm 13.0 \mathrm{mV}\right)$, and it also reversed the increase in spike threshold (control, $-53.7 \pm 15.3 \mathrm{mV}$; quinpirole, $-48.9 \pm 27 \mathrm{mV}$; $\mathrm{Cs}^{+},-58.2 \pm 2.8 \mathrm{mV} ; n=3$ ) (Fig. 9). In addition, in the presence of $\mathrm{Cs}^{+}$, quinpirole failed to produce facilitation of the LTS.

As a further test of the specificity of this response, recordings were performed under conditions in which the $\mathrm{Ca}^{2+}$ in the superfusate had been replaced with $\mathrm{Co}^{2+}$. In cases in which the buffer was switched before quinpirole administration, facilitation of the LTS by quinpirole did not occur; however, quinpirole administration was still capable of causing a depolarization of the membrane potential $(12 \mathrm{mV}$; RMP control $=-68.6 \pm 5.8$; quinpirole $\left.+\mathrm{Co}^{2+}=-56.3 \pm 0.3 \mathrm{mV}\right)$. In the cases in which the switch to $\mathrm{Ca}^{2+}$-free- $\mathrm{Co}^{2+}$ buffer was made after quinpirole administration, the facilitation of the LTS by quinpirole was abolished, and the spike threshold was returned to control values (control, -47.1 mV; quinpirole, $-33.7 \mathrm{mV}$; $\mathrm{Co}^{2+},-42.3 \mathrm{mV}$ ) (Fig. 9).

\section{DISCUSSION}

These experiments show that stimulation of DA D2 receptors by quinpirole resulted in changes in the passive membrane properties of thalamic neurons. More specifically, administration of the D2 agonist quinpirole but not the D1 agonist SKF 38393 enhanced the excitability of MD thalamic neurons in two ways: (1) it increased the response of the neuron to depolarizing current pulses and (2) it facilitated the occurrence of LTSs at membrane potential values at which these spikes were not typically triggered. The experiments with $\mathrm{Co}^{2+}, \mathrm{Cs}^{+}$, and different potassium concentrations indicated that these effects occurred, at least in part, via changes in $\mathrm{K}^{+}$conductances. The $\mathrm{D} 2$ selectivity of the
Figure 6. Effects of quinpirole on the voltage-dependent modulation of the rate of rise of the LTS. When the first derivative of the LTS amplitude was plotted against the membrane potential, the data between -65 and $-85 \mathrm{mV}$ could be fit to a sigmoidal function. Furthermore, quinpirole appeared to facilitate the LTS for membrane potential values between -65 and $-70 \mathrm{mV}$. However, for values of membrane potential between -56 and $-65 \mathrm{mV}$, quinpirole caused a substantially larger facilitation of LTSs but could not be fitted to a sigmoidal function. Every point represents the average of seven cells collected during control conditions $(\bullet)$ and after quinpirole administration $(\bigcirc)$.

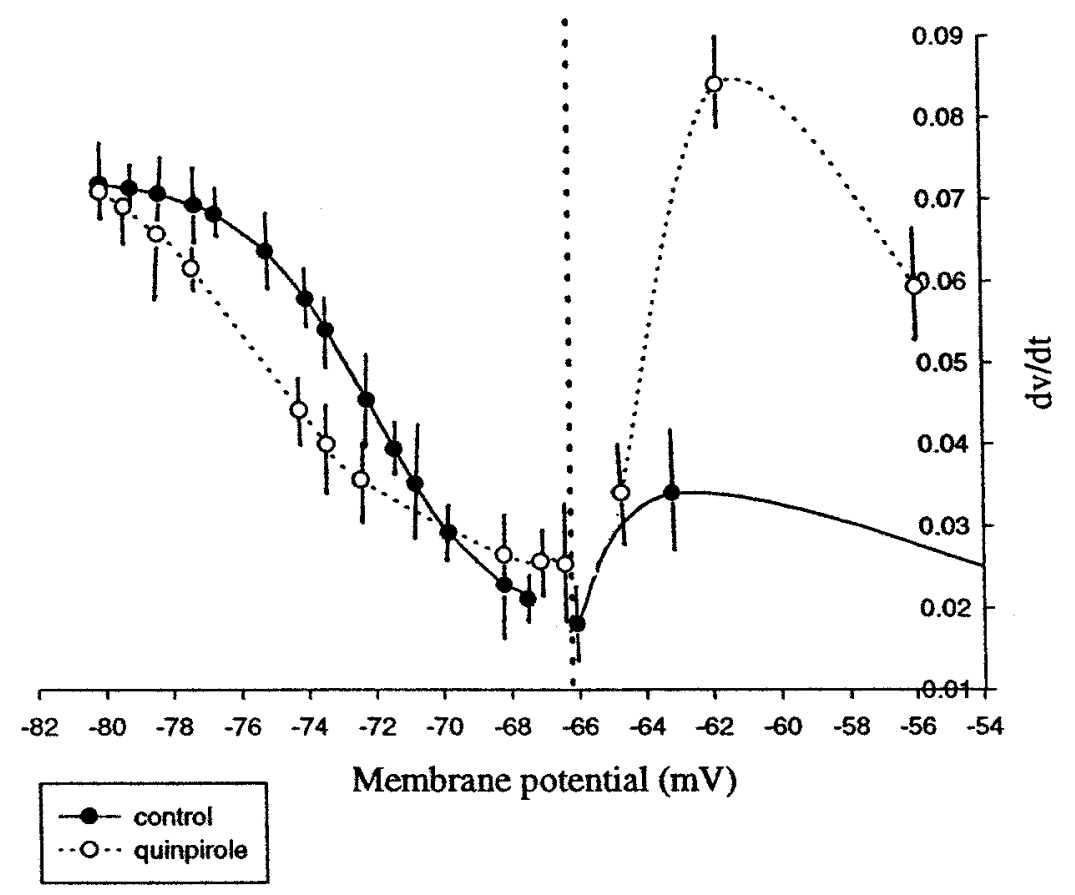




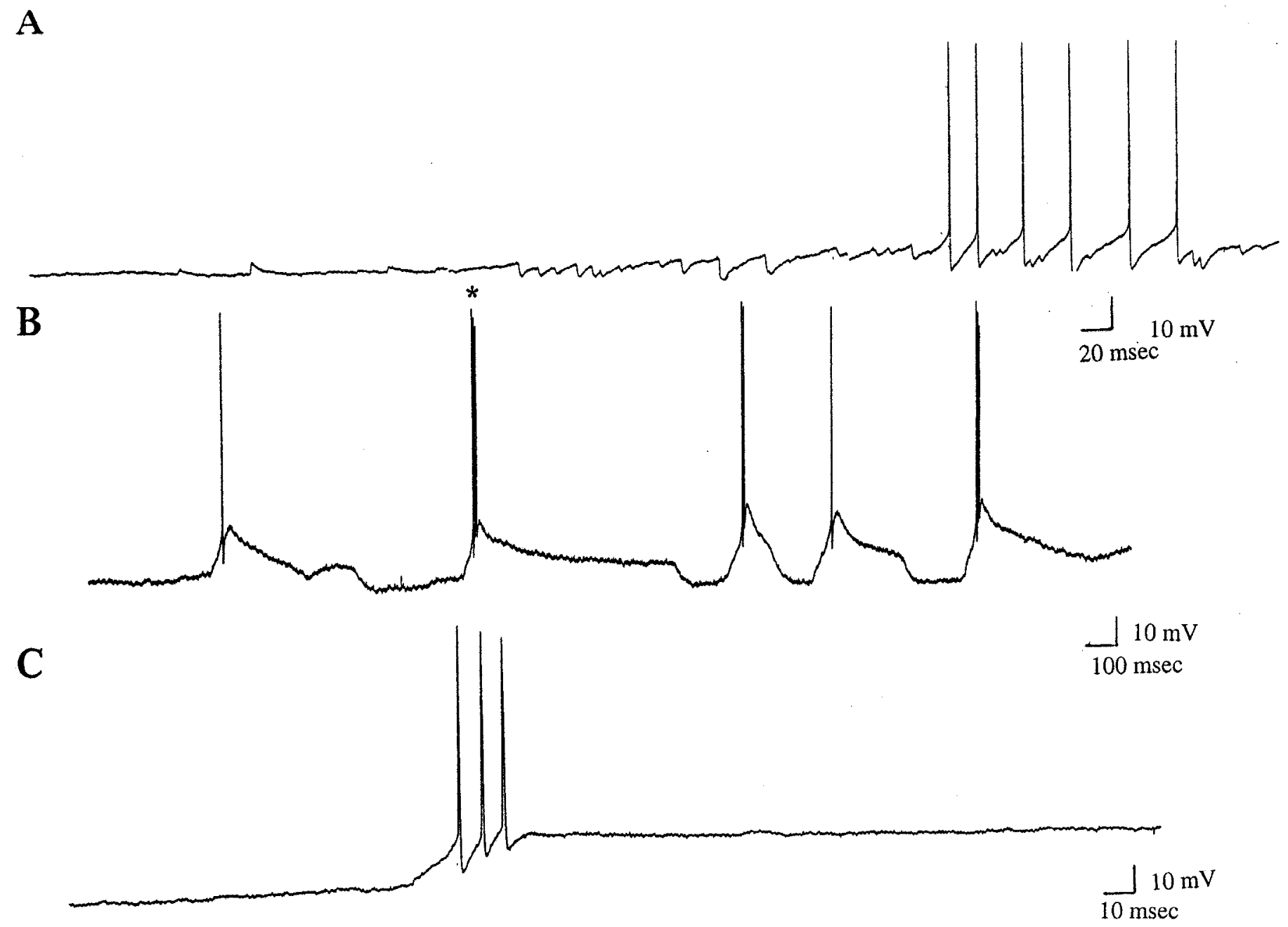

Figure 7. Effects of quinpirole administration on spontaneous spike activity of thalamic neurons recorded in vitro. Although thalamic neurons rarely exhibit spontaneous spike discharge in vitro, quinpirole administration was found to trigger spontaneous activity in these cells. $A$, After quinpirole administration $(10 \mu \mathrm{M})$, a gradual increase in depolarizing events was found to give rise to full action potentials firing in a tonic-like pattern. $B$, Quinpirole administration caused this neuron to initiate spontaneous action potential firing in a burst-like pattern, with spikes riding on top of LTSs. $C$, Shown at faster time base, the burst $(B$, asterisk) was found to consist of three action potentials.

Table 3. Effects of haloperidol on basic membrane properties of thalamic cells

\begin{tabular}{lllc} 
& Control & Quinpirole & Haloperidol \\
\hline Membrane potential $(\mathrm{mV})$ & $68.6 \pm 3.1$ & $72.4 \pm 7.7$ & $65.7 \pm 3.1$ \\
Input resistance $(\mathrm{M} \Omega)$ & $48.4 \pm 17.8$ & $59.9 \pm 22.7$ & $51.6 \pm 22.0$ \\
Spike threshold $(\mathrm{mV})$ & $46.2 \pm 0.12$ & $47.2 \pm 5.2$ & $43.7 \pm 12.5$ \\
Current threshold $(\mathrm{nA})$ & $0.37 \pm 0.12$ & $0.34 \pm 0.11$ & $0.23 \pm 0.29$ \\
LTS-evoked (rebound) & $0 / 5$ & $2 / 5$ & $0 / 5$
\end{tabular}

quinpirole-mediated responses was further substantiated by the ability of the preferential D2 antagonist haloperidol to reverse these effects.

\section{Dopaminergic agonist effects on MD cell excitability}

Overall, bath application of either the D1 or D2 agonist to MD cells either failed to alter or produced small and inconsistent changes in resting membrane potential. Although the administration of the D1 agonist SKF 38393 did not appear to change the RMP in any of the cells tested, the D2 agonist quinpirole caused a hyperpolarization in approximately half of the neurons tested, with the remaining cells showing either a small depolarization or no changes in RMP. Neither agonist produced significant changes in the input resistance of these neurons.

In contrast, the most consistent effect produced by the D2 agonist quinpirole was to increase the overall excitability of all MD cells tested, with excitability defined on the basis of the amount of depolarizing current required to evoke a spike. This increase in excitability occurred independent of the effects of quinpirole on resting membrane potential. In other systems, DA has been reported to exert variable effects on excitability. In the striatum, DA appears to decrease excitability of striatal cells via D1- and D2-dependent mechanisms (Norcross and Spehlmann, 1978; Mercuri et al., 1985; Uchimura et al., 1986; Calabresi et al., 1987; Hu and Wang, 1988; Hu et al., 1990; Akaoka et al., 1992; Hernandez-Lopez et al., 1997), although DA has been reported to increase the excitation produced by NMDA receptor activation (Cepeda et al., 1993). In contrast, in the cortex, DA appears to increase excitability through a D1-dependent mechanism (Bernardi et al., 1982; Penit-Soria et al., 1987; Yang and Seamans, 1996; Shi et al., 1997). In the ventral pallidum it has been reported 

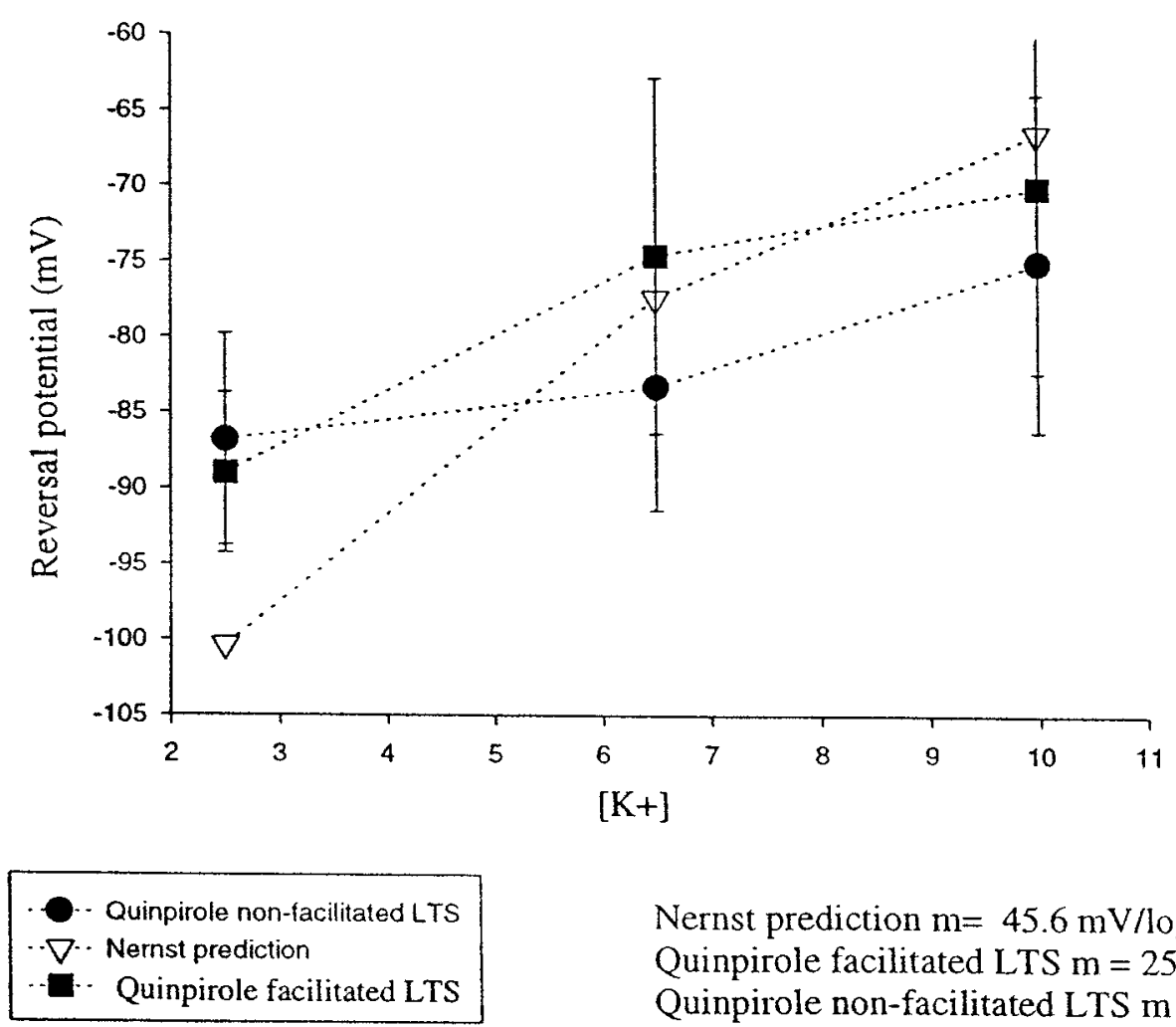

\author{
Nernst prediction $\mathrm{m}=45.6 \mathrm{mV} / \mathrm{log}$ unit \\ Quinpirole facilitated LTS $\mathrm{m}=25.5 \mathrm{mV} / \mathrm{log}$ unit \\ Quinpirole non-facilitated LTS $\mathrm{m}=15.5 \mathrm{mV} / \mathrm{log}$ unit
}

Figure 8. Effects of varying the potassium concentration in the superfusion medium on the reversal potential of the quinpirole-mediated membrane hyperpolarization. The plot shows the reversal potential of quinpirole in cells that also exhibited a quinpirole-induced facilitation of the LTS (quinpirole-facilitated LTS) and in cells in which the LTS was not affected by quinpirole (nonfacilitated LTS) at $2.5,6.5$, and 10 mM $\mathrm{K}^{+}$concentrations. In comparison, the $\mathrm{K}^{+}$reversal potentials as determined by the Nernst equation are illustrated. Quinpirole was found to shift the reversal potential at low $\left[\mathrm{K}^{+}\right]$concentration to more positive values, whereas at higher $\left[\mathrm{K}^{+}\right]$concentrations quinpirole shifted the reversal potential to more negatives values.

that $72 \%$ of the cells tested were inhibited by iontophoretic application of DA, whereas $27 \%$ were excited (Maslowski and Napier, 1991). However, this is the first report in which DA is observed to affect cell excitability via an effect on the LTSs.

\section{Facilitation of low-threshold spikes by quinpirole}

In this study, quinpirole was found to increase the probability of evoking an LTS in MD thalamic neurons. The LTS is considered to be an important property for regulating thalamocortical function. Electrophysiological studies have revealed that thalamic neurons have two basic modes of firing: tonic single-spike activity and a rhythmic burst-firing pattern (Deschênes al., 1984; Steriade and Deschênes, 1984; Steriade and Llinás, 1988; McCormick and Pape, 1990) in which the burst activity is driven by LTSs (Steriade and Deschênes, 1984). In contrast, tonic spike activity predominates during waking states or rapid eye movement (REM) sleep. The tonic firing is associated with depolarized membrane potentials $(-50$ to $-55 \mathrm{mV})$. In this state the cells are depolarized by a pacemaker potential and repolarized by depolarizationactivated $\mathrm{K}^{+}$currents to produce the tonic firing pattern (Jahnsen and Llinás, 1984). The bursting firing pattern is characteristic of slow-wave sleep, deep anesthesia, or absence seizures (Hirsch et al., 1983; McCarley et al., 1983; Fourment et al., 1985; Gloor and Fariello, 1988; Buzsaki et al., 1990; Curro Dossi et al., 1991; Steriade et al., 1991). The burst firing of thalamic cells is reported to be caused by a $\mathrm{Ca}^{2+}$-mediated LTS (Jahnsen and Llinás, 1984; Steriade and Deschênes, 1984; Coulter et al., 1989; Crunelli et al., 1989; Hernandez-Cruz and Pape, 1989). This low-threshold $\mathrm{Ca}^{2+}$ conductance is deinactivated at $-55 \mathrm{mV}$, reaching a maximum level of deinactivation at $-75 \mathrm{mV}$ (Llinás and Jahnsen, 1982). The faster activation time course of the $\mathrm{Ca}^{2+}$ current allows depolarization from hyperpolarized membrane potentials to generate LTSs that in turn activate one to eight high-frequency $\mathrm{Na}^{+}$spikes that occur at frequencies of 250-500 $\mathrm{Hz}$. In many cases (10 of 15 in the present study), the occurrence of the LTS was linked to quinpirole-induced hyperpolarization of the membrane potential. Furthermore, blockade of $\mathrm{K}^{+}$conductances by $\mathrm{Cs}^{+}$reversed the effect of quinpirole on the membrane potential and caused the facilitated LTS discharge to be replaced by a tonic spike-firing pattern. Although the mechanisms through which DA facilitates the LTS are unknown, several possibilities may be advanced based on these data and in comparison with other systems. In fact, a persistent sodium conductance $\left(I_{\mathrm{NaP}}\right)$ has recently been described in thalamocortical neurons (Parri and Crunelli, 1998). The activation of this $I_{\mathrm{NaP}}$ at relatively negative potentials (approximately $-70 \mathrm{mV}$ ) is consistent with a potential involvement of this conductance in the generation of the LTSs. Because the D2 agonist quinpirole has been shown to play a role in the modulation of TTX-sensitive $\mathrm{Na}^{+}$currents, we cannot exclude the possibility that the effects produced by quinpirole in the MD may be mediated by a modulation of this $I_{\mathrm{NaP}}$.

\section{D2 receptor-mediated regulation of $\mathrm{K}^{+}$conductances}

As reviewed above, the most consistent effect produced by quinpirole administration was a significant increase in MD cell excit- 


\section{A1 Control A2 Quinpirole A3 Quinpirole $+\mathrm{Cs}^{+}$}
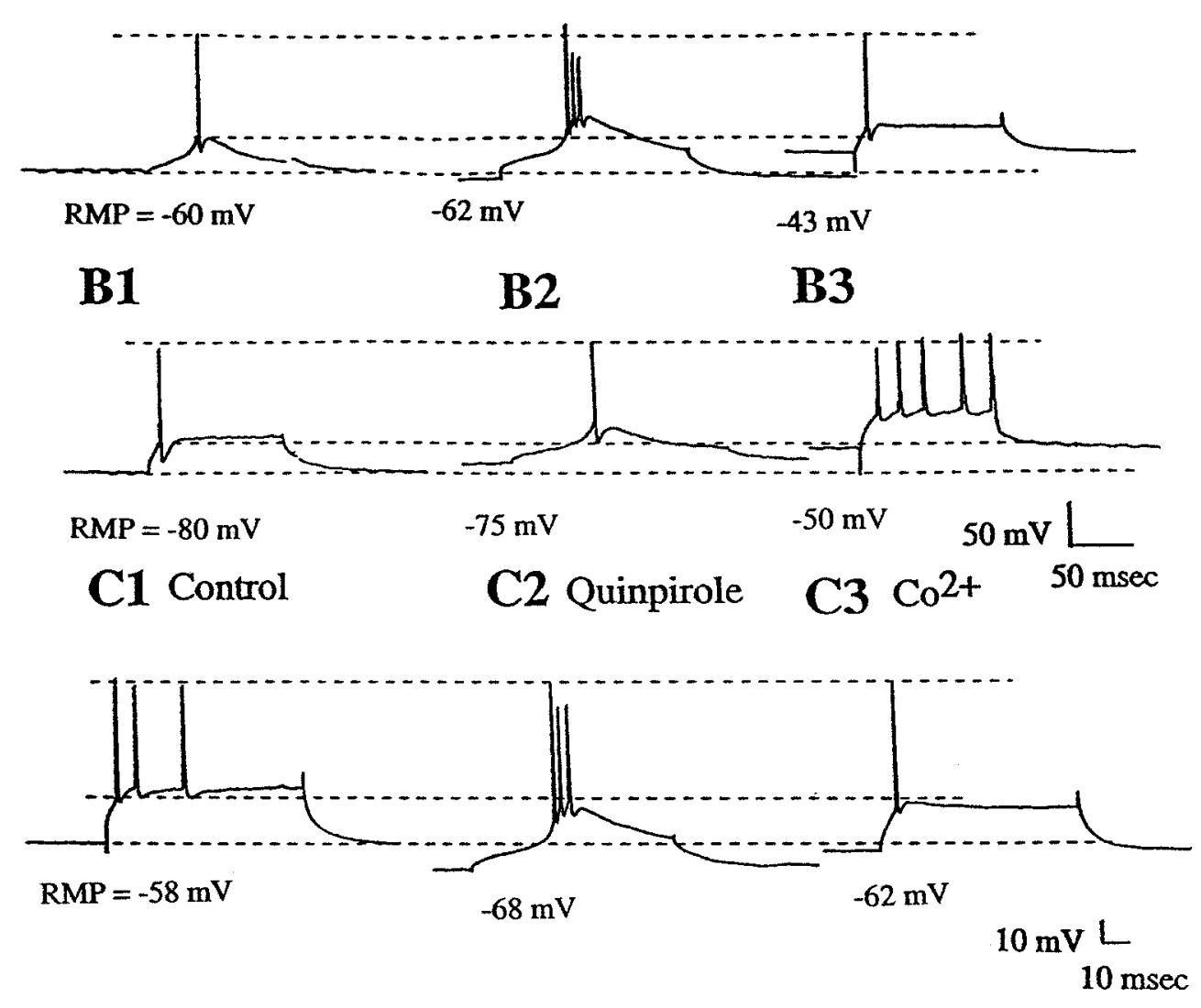

Figure 9. The effects of the $\mathrm{K}^{+}$blocker $\mathrm{Cs}^{+}$and the calcium blocker $\mathrm{Co}^{2+}$ on the quinpirole-mediated alteration of LTSs. $A$, MD thalamus neurons exhibit prominent LTSs. A1, Control. A2, Quinpirole administration $(10 \mu \mathrm{M})$ caused a 2 $\mathrm{mV}$ hyperpolarization of the membrane potential and increased the prominence of the LTSs. $A 3$, Administration of $\mathrm{Cs}^{+}$ $(2 \mathrm{mM})$ in the presence of quinpirole abolished the LTSs without altering spike discharge. $B$, MD thalamus neuron without prominent LTSs. B1, Control. B2, Quinpirole administration (10 $\mu \mathrm{M}$ ) caused a $5 \mathrm{mV}$ depolarization of the membrane potential and a facilitation of LTS occurrence. B3, Administration of $\mathrm{Cs}^{+}(2 \mathrm{mM})$ abolished the LTS and caused the cell to fire in a tonic discharge pattern. $C$, Effects of calcium blockade on two responses to quinpirole. C1, Control. C2, Administration of quinpirole $(10 \mu \mathrm{M})$ caused a $10 \mathrm{mV}$ hyperpolarization of the neuron and facilitation of the LTS. C3, Replacement of calcium in the superfusion medium by $\mathrm{Co}^{2+}(2.4 \mathrm{mM})$ abolished the LTSs. The bottom dashed line indicates the RMP, the middle dashed line indicates the spike threshold during the control period, and the top dashed line represents the peak amplitude of the action potential. ability, which appears to be related at least in part to quinpiroleinduced facilitation of the LTS. Examination of the effects of varying $\mathrm{K}^{+}$concentrations and the reversal of these actions by the $\mathrm{K}^{+}$channel blocker cesium supports a $\mathrm{K}^{+}$-dependent mechanism for the D2 response. One possible conductance change that could account for these actions is a D2-dependent modulation of the $I_{\mathrm{h}}$. This $\mathrm{Na}^{+} / \mathrm{K}^{+}$current is reported to underlie the pacemaker potential that produces the slow depolarizations between spikes in the thalamus (for review, see McCormick, 1992). The rate at which the $I_{\mathrm{h}}$ is activated can determine the delay period between subsequent LTSs. Alternately, the $\mathrm{I}_{\mathrm{h}}$ may also be affecting the LTS by shifting its apparent voltage dependence to more depolarized levels, at least as measured at the soma. In this manner, quinpirole could produce its observed effects on the LTS by combined effects on $I_{\mathrm{h}}, \mathrm{K}^{+}$currents, and modulation of LTS threshold. As a result, the LTS would be evoked at more depolarized RMPs and allow the triggering of $\mathrm{Na}^{+}$spikes at these more depolarized membrane potentials. The fact that the excitability is increased independent of the effect of quinpirole on RMP or spike threshold would be consistent with these events and the fact that the reversal potential for quinpirole is shifted to more positive potentials at low $\left[\mathrm{K}^{+}\right]$. However, the significant increase in onset latency for spikes evoked after quinpirole administration suggests that the D2 agonist also may be activating $I_{\mathrm{K}(\mathrm{A})}$ currents. In neurons of the substantia nigra zona compacta, DA administration has been shown to hyperpolarize the resting potential (Lacey et al., 1987, 1989), and using voltage-clamp techniques this was shown to be mediated by a DA-activated conductance. The reversal potential of this outward current was reported to be close to the reversal potential for $\mathrm{K}^{+}$(Lacey et al., 1987, 1989). Pharmacological manipulations demonstrated that this effect was caused by D2 receptor stimulation. In the experiments presented here, quinpirole also produced a hyperpolarization in 19 of 32 neurons and in three cases increased the amplitude of the AHP following action potentials. The reversal potential for the quinpirole-mediated hyperpolarization, its dependence on extracellular $\mathrm{K}^{+}$concentration, and its blockade by $\mathrm{Cs}^{+}$suggest that this is mediated by a change in a $\mathrm{K}^{+}$conductance as well. However, because the change in the quinpirole reversal potential did not precisely follow the predictions of the Nernst equation with respect to alterations in $\mathrm{K}^{+}$concentrations, other factors may also play a role in this response. Nonetheless, a quinpirole-mediated change in $\mathrm{K}^{+}$conductance could account for each of the findings reported here, including (1) hyperpolarization of the membrane potential, (2) facilitation of LTS spiking, (3) the increase in spike threshold, (4) the augmentation of the AHP, and (5) the increase in onset spike latency.

\section{A proposed role of DA in the modulation of thalamocortical activity}

DA has been postulated to play a role in learning processes and goal-directed behavior (Le Moal and Simon, 1991), sensory information processing (Clark and White, 1987), and time perception (Rammsayer, 1989). The thalamus is also likely to play a role 
in such processes, because lesions of the reticular thalamic nucleus, which regulates thalamic rhythmic activity (Steriade and Deschênes, 1984; Steriade and Llinás, 1988), lead to confusional states and deficits in information processing (Friedberg and Ross, 1993). Moreover, studies have shown that rhythmic activity states underlying sleep stages are a result of thalamocortical interactions (Steriade and Deschênes, 1984; Steriade and Llinás, 1988), and REM sleep deprivation can lead to disorganized thinking and abnormal social behavior in humans (Spiegel, 1982; Naitoh et al., 1990) that has been compared with a state of acute psychosis (Gove, 1970). It is interesting to note that in studies in rats, sleep deprivation has been associated with alterations in D2 receptor density in MD thalamic target regions (Brooks et al., 1995).

These correlations may have functional implications with respect to the results presented here. Thus, because D2 stimulation enhances rhythmic activity in the thalamus, alterations in D2 stimulation could be predicted to lead to abnormalities in thalamocortical rhythms. Moreover, nonmedicated schizophrenics have been reported to show abnormalities in slow-wave sleep (Keshavan et al., 1995) that have been correlated with the state of spindle activity and synchronization of cortical activity (Steriade and Deschênes, 1984; Steriade and Llinás, 1988). Indeed, it has been proposed that a combination of increased activity of dopaminergic and cholinergic neurons could explain most of the sleep disturbances observed in schizophrenics (Tandon and Greden, 1989; Tandon et al., 1990, 1992). Within this framework, one possibility is that the proposed decrease in tonic DA in schizophrenics (Grace, 1991) may underlie some of the sleep disturbances and EEG alterations observed in these patients.

\section{REFERENCES}

Aizawa H, Kwak S, Shimizu T, Mannen T, Shibasaki H (1991) A case of adult onset pure pallidal degeneration. II. Analysis of neurotransmitter markers, with special reference to the termination of pallidothalamic tract in human brain. J Neurol Sci 102:83-91.

Akaoka H, Charlety P, Saunier CF, Buda M, Chouvet G (1992) Inhibition of nigral dopamine neurons by systemic and local apomorphine: possible contribution of dendritic autoreceptors. Neuroscience 49:879-891.

Andreasen NC, Swayze V, O'Leary DS, Nopoulos P, Cizadlo T, Harris G, Arndt S, Flaum M (1995) Abnormalities in midline attentional circuitry in schizophrenia: evidence from magnetic resonance and positron emission tomography. Eur Neuropsychopharmacol 5:37-41.

Beckstead RM, Domesick VB, Nauta WJ (1979) Efferent connections of the substantia nigra and ventral tegmental area in the rat. Brain Res 175:191-217.

Berendse HW, Groenewegen HJ (1991) Restricted cortical termination fields of the midline and intralaminar thalamic nuclei in the rat. Neuroscience 42:73-102.

Bernardi G, Cherubini E, Marciani MG, Mercuri N, Stanzione P (1982) Responses of intracellularly recorded cortical neurons to the iontophoretic application of dopamine. Brain Res 245:267-274.

Blennow K, Davidsson P, Gottfries CG, Ekman R, Heilig M (1996) Synaptic degeneration in thalamus in schizophrenia. Lancet 348:692-693.

Boyson SJ, McGonigle P, Molinoff PB (1986) Quantitative autoradiographic localization of the D1 and D2 subtypes of dopamine receptors in rat brain. J Neurosci 6:3177-3188.

Brooks DJ, Torjanski N, Burn DJ (1995) Ropinirole in the symptomatic treatment of Parkinson's disease. J Neural Transm [Suppl] 45:231-238.

Buchsbaum MS, Someya T, Teng CY, Abel L, Chin S, Najafi A, Haier RJ, Wu J, Bunney WE, Jr (1996) PET and MRI of the thalamus in never-medicated patients with schizophrenia. Am J Psychiatry 153:191-199.
Buzsaki G, Laszlovszky I, Lajtha A, Vadasz C (1990) Spike-and-wave neocortical patterns in rats: genetic and aminergic control. Neuroscience 38:323-333.

Calabresi P, Mercuri N, Stanzione P, Stefani A, Bernardi G (1987) Intracellular studies on the dopamine-induced firing inhibition of neostriatal neurons in vitro: evidence for D1 receptor involvement. Neuroscience 20:757-771.

Camps M, Cortes R, Gueye B, Probst A, Palacios JM (1989) Dopamine receptors in human brain: autoradiographic distribution of D2 sites. Neuroscience 28:275-290.

Carlsson M, Carlsson A (1990) Interactions between glutamatergic and monoaminergic systems within the basal ganglia-implications for schizophrenia and Parkinson's disease. Trends Neurosci 13:272-276.

Cepeda C, Buchwald NA, Levine MS (1993) Neuromodulatory actions of dopamine in the neostriatum are dependent upon the excitatory amino acid receptor subtypes activated. Proc Natl Acad Sci USA 90:9576-9580.

Civelli O, Bunzow JR, Grandy DK (1993) Molecular diversity of the dopamine receptors. Annu Rev Pharmacol Toxicol 33:281-307.

Clark D, White FJ (1987) D1 dopamine receptor-the search for a function: a critical evaluation of the D1/D2 dopamine receptor classification and its functional implications. Synapse 1:347-388.

Cornwall J, Phillipson OT (1988) Afferent projections to the dorsal thalamus of the rat as shown by retrograde lectin transport. II. The midline nuclei. Brain Res Bull 21:147-161.

Coulter DA, Huguenard JR, Prince DA (1989) Calcium currents in rat thalamocortical relay neurones: kinetic properties of the transient, low-threshold current. J Physiol (Lond) 414:587-604.

Crunelli V, Lightowler S, Pollard CE (1989) A T-type Ca ${ }^{2+}$ current underlies low-threshold $\mathrm{Ca}^{2+}$ potentials in cells of the cat and rat lateral geniculate nucleus. J Physiol (Lond) 413:543-561.

Curro Dossi R, Pare D, Steriade M (1991) Short-lasting nicotinic and long-lasting muscarinic depolarizing responses of thalamocortical neurons to stimulation of mesopontine cholinergic nuclei. J Neurophysiol 65:393-406.

Dawson TM, Barone P, Sidhu A, Wamsley JK, Chase TN (1986) Quantitative autoradiographic localization of D-1 dopamine receptors in the rat brain: use of the iodinated ligand [125I]SCH 23982. Neurosci Lett 68:261-266.

Deschênes M, Paradis M, Roy JP, Steriade M (1984) Electrophysiology of neurons of lateral thalamic nuclei in cat: resting properties and burst discharges. J Neurophysiol 51:1196-1219.

Fields JZ, Reisine TD, Yamamura HI (1977) Biochemical demonstration of dopaminergic receptors in rat and human brain using $[3 \mathrm{H}] \mathrm{spi}-$ roperidol. Brain Res 136:578-584.

Fourment A, Hirsch JC, Marc ME (1985) Oscillations of the spontaneous slow-wave sleep rhythm in lateral geniculate nucleus relay neurons of behaving cats. Neuroscience 14:1061-1075.

Freedman JE, Weight FF (1988) Single K+ channels activated by D2 dopamine receptors in acutely dissociated neurons from rat corpus striatum. Proc Natl Acad Sci USA 85:3618-3622.

Freedman JE, Weight FF (1989) Quinine potently blocks single K+ channels activated by dopamine D-2 receptors in rat corpus striatum neurons. Eur J Pharmacol 164:341-346.

Friedberg EB, Ross DT (1993) Degeneration of rat thalamic reticular neurons following intrathalamic domoic acid injection. Neurosci Lett 151:115-119.

Fuxe K (1965) Evidence for the existence of monoamine neurons in the central nervous system. IV. Distribution of nerve terminals in the central nervous system. Acta Physiol Scand 64[Suppl 247]:37-84.

Gloor P, Fariello RG (1988) Generalized epilepsy: some of its cellular mechanisms differ from those of focal epilepsy. Trends Neurosci 11:63-68.

Gove WR (1970) Sleep deprivation: a cause of psychotic disorganization. Am J Soc 75:782-799.

Grace AA (1991) Phasic versus tonic dopamine release and the modulation of dopamine system responsivity: a hypothesis for the etiology of schizophrenia. Neuroscience 41:1-24.

Greif GJ, Lin YJ, Liu JC, Freedman JE (1995) Dopamine-modulated potassium channels on rat striatal neurons: specific activation and cellular expression. J Neurosci 15:4533-4544.

Groenewegen HJ (1988) Organization of the afferent connections of the mediodorsal thalamic nucleus in the rat, related to the mediodorsalprefrontal topography. Neuroscience 24:379-431.

Groenewegen HJ, Berendse HW (1994) The specificity of the "nonspecific" midline and intralaminar thalamic nuclei. Trends Neurosci 17:52-57. 
Haber SN, Groenewegen HJ, Grove EA, Nauta WJ (1985) Efferent connections of the ventral pallidum: evidence of a dual striato pallidofugal pathway. J Comp Neurol 235:322-335.

Hall H, Halldin C, Dijkstra D, Wikstrom H, Wise LD, Pugsley TA, Sokoloff P, Pauli S, Farde L, Sedvall G (1996) Autoradiographic localisation of D3-dopamine receptors in the human brain using the selective D3-dopamine receptor agonist (+)-[3H]PD 128907. Psychopharmacology 128:240-247.

Heckers S (1997) Neuropathology of schizophrenia: cortex, thalamus, basal ganglia, and neurotransmitter-specific projection systems. Schizophr Bull 23:403-421.

Hernandez-Cruz A, Pape HC (1989) Identification of two calcium currents in acutely dissociated neurons from the rat lateral geniculate nucleus. J Neurophysiol 61:1270-1283.

Hernandez-Lopez S, Bargas J, Surmeier DJ, Reyes A, Galarraga E (1997) D1 receptor activation enhances evoked discharge in neostriatal medium spiny neurons by modulating an L-type $\mathrm{Ca}^{2+}$ conductance. J Neurosci 17:3334-3342.

Hirsch JC, Fourment A, Marc ME (1983) Sleep-related variations of membrane potential in the lateral geniculate body relay neurons of the cat. Brain Res 259:308-312.

Hu XT, Wang RY (1988) Comparison of effects of D-1 and D-2 dopamine receptor agonists on neurons in the rat caudate putamen: an electrophysiological study. J Neurosci 8:4340-4348.

Hu XT, Wachtel SR, Galloway MP, White FJ (1990) Lesions of the nigrostriatal dopamine projection increase the inhibitory effects of D1 and D2 dopamine agonists on caudate-putamen neurons and relieve D2 receptors from the necessity of D1 receptor stimulation. J Neurosci 10:2318-2329.

Huang Q, Zhou D, Chase K, Gusella JF, Aronin N, DiFiglia M (1992) Immunohistochemical localization of the D1 dopamine receptor in rat brain reveals its axonal transport, pre- and postsynaptic localization, and prevalence in the basal ganglia, limbic system, and thalamic reticular nucleus. Proc Natl Acad Sci USA 89:11988-11992.

Jahnsen H, Llinás R (1984) Electrophysiological properties of guineapig thalamic neurones: an in vitro study. J Physiol (Lond) 349:205-226.

Janowsky A, Neve KA, Kinzie JM, Taylor B, de Paulis T, Belknap JK (1992) Extrastriatal dopamine D2 receptors: distribution, pharmacological characterization and region-specific regulation by clozapine. J Pharmacol Exp Ther 261:1282-1290.

Keshavan MS, Miewald J, Haas G, Sweeney J, Ganguli R, Reynolds CF (1995) Slow-wave sleep and symptomatology in schizophrenia and related psychotic disorders. J Psychiatr Res 29:303-314.

Lacey MG, Mercuri NB, North RA (1987) Dopamine acts on D2 receptors to increase potassium conductance in neurones of the rat substantia nigra zona compacta. J Physiol (Lond) 392:397-416.

Lacey MG, Mercuri NB, North RA (1988) On the potassium conductance increase activated by GABAB and dopamine $\mathrm{D} 2$ receptors in rat substantia nigra neurones. J Physiol (Lond) 401:437-453.

Lacey MG, Mercuri NB, North RA (1989) Two cell types in rat substantia nigra zona compacta distinguished by membrane properties and the actions of dopamine and opioids. J Neurosci 9:1233-1241.

Lavin A, Grace AA (1994) Modulation of dorsal thalamic cell activity by the ventral pallidum: its role in the regulation of thalamocortical activity by the basal ganglia. Synapse 18:104-127.

Le Moal M, Simon H (1991) Mesocorticolimbic dopaminergic network: functional and regulatory roles. Physiol Rev 71:155-234.

Levant B, Grigoriadis DE, DeSouza EB (1992) Characterization of [3H]quinpirole binding to D2-like dopamine receptors in rat brain. J Pharmacol Exp Ther 262:929-935.

Lindvall O, Björklund A (1974) The organization of the ascending catecholamine neuron systems in the rat brain as revealed by the glyoxylic acid fluorescence method. Acta Physiol Scand [Suppl] 412:1-48.

Liu L, Shen RY, Kapatos G, Chiodo LA (1994) Dopamine neuron membrane physiology: characterization of the transient outward current (IA) and demonstration of a common signal transduction pathway for IA and IK. Synapse 17:230-240.

Llinás R, Sugimori M (1980) Electrophysiological properties of in vitro Purkinje cell somata in mammalian cerebellar slices. J Physiol (Lond) 305:171-195.

Llinás, R Jahnsen H (1982) Electrophysiology of mammalian thalamic neurons in vitro. Nature 297:406-408.

Machida CA, Searles RP, Nipper V, Brown JA, Kozell LB, Neve KA (1992) Molecular cloning and expression of the rhesus macaque D1 dopamine receptor gene. Mol Pharmacol 41:652-659.

Mansour A, Meador-Woodruff JH, Bunzow JR, Civelli O, Akil H, Watson
SJ (1990) Localization of dopamine D2 receptor mRNA and D1 and D2 receptor binding in the rat brain and pituitary: an in situ hybridizationreceptor autoradiographic analysis. J Neurosci 10:2587-2600.

Mansour A, Meador-Woodruff JH, Zhou Q, Civelli O, Akil H, Watson SJ (1992) A comparison of D1 receptor binding and mRNA in rat brain using receptor autoradiographic and in situ hybridization techniques. Neuroscience 46:959-971.

Maslowski RJ, Napier TC (1991) Dopamine D1 and D2 receptor agonists induce opposite changes in the firing rate of ventral pallidal neurons. Eur J Pharmacol 200:103-112.

McCarley RW, Benoit O, Barrionuevo G (1983) Lateral geniculate nucleus unitary discharge in sleep and waking: state- and rate-specific aspects. J Neurophysiol 50:798-818.

McCormick DA (1992) Neurotransmitter actions in the thalamus and cerebral cortex and their role in neuromodulation of thalamocortical activity. Prog Neurobiol 39:337-388.

McCormick DA, Pape HC (1990) Properties of a hyperpolarizationactivated cation current and its role in rhythmic oscillation in thalamic relay neurones. J Physiol (Lond) 431:291-318.

Mercuri N, Bernardi G, Calabresi P, Cotugno A, Levi G, Stanzione P (1985) Dopamine decreases cell excitability in rat striatal neurons by pre- and postsynaptic mechanisms. Brain Res 358:110-121.

Naitoh P, Kelly TL, Englund C (1990) Health effects of sleep deprivation. Occup Med 5:209-237.

Norcross K, Spehlmann R (1978) Decreased sensitivity of caudatal neurons to microiontophoretic dopamine in dopamine-depleted caudate nucleus. Brain Res 156:175-180.

Oke A, Lewis R, Adams RN (1980) Hemispheric asymmetry of norepinephrine distribution in rat thalamus. Brain Res 188:269-272.

Oke A, Solnick J, Adams RN (1983) Catecholamine distribution patterns in rat thalamus. Brain Res 269:180-183.

Pakkenberg B (1990) Pronounced reduction of total neuron number in mediodorsal thalamic nucleus and nucleus accumbens in schizophrenics. Arch Gen Psychiatry 47:1023-1028.

Parri HR, Crunelli V (1998) Sodium current in rat and cat thalamocortical neurons: role of a non-inactivating component in tonic and burst firing. J Neurosci 18:854-867.

Paxinos G, Watson C (1986) The rat brain in stereotaxic coordinates. San Diego: Academic.

Penit-Soria J, Audinat E, Crepel F (1987) Excitation of rat prefrontal cortical neurons by dopamine: an in vitro electrophysiological study. Brain Res 425:263-274.

Rammsayer T (1989) Is there a common dopaminergic basis of time perception and reaction time? Neuropsychobiology 21:37-42.

Santiago M, Machado A, Cano J (1989) Age-related changes of catecholamines and their metabolites content in the visual system of the rat. Mech Ageing Dev 47:77-84.

Sedvall G, Farde L (1996) Dopamine receptors in schizophrenia. Lancet 347:264.

Seeman P, Van Tol HH (1994) Dopamine receptor pharmacology. Trends Pharmacol Sci 15:264-270.

Shi WX, Zheng P, Liang XF, Bunney BS (1997) Characterization of dopamine-induced depolarization of prefrontal cortical neurons. Synapse 26:415-422.

Spiegel R (1982) Aspects of sleep, daytime vigilance, mental performance and psychotropic drug treatment in the elderly. Gerontology 28:68-82.

Steriade M, Deschênes M (1984) The thalamus as a neuronal oscillator. Brain Res 320:1-63.

Steriade M, Llinás RR (1988) The functional states of the thalamus and the associated neuronal interplay. Physiol Rev 68:649-742.

Steriade M, Dossi RC, Nuñez A (1991) Network modulation of a slow intrinsic oscillation of cat thalamocortical neurons implicated in sleep delta waves: cortically induced synchronization and brainstem cholinergic suppression. J Neurosci 11:3200-3217.

Surmeier DJ, Kitai ST (1993) D1 and D2 dopamine receptor modulation of sodium and potassium currents in rat neostriatal neurons. Prog Brain Res 99:309-324.

Tandon R, Greden JF (1989) Cholinergic hyperactivity and negative schizophrenic symptoms. A model of cholinergic/dopaminergic interactions in schizophrenia. Arch Gen Psychiatry 46:745-753.

Tandon R, Mann NA, Eisner WH, Coppard N (1990) Effect of anticholinergic medication on positive and negative symptoms in medicationfree schizophrenic patients. Psychiatry Res 31:235-241.

Tandon R, Shipley JE, Taylor S, Greden JF, Eiser A, DeQuardo J, Goodson J (1992) Electroencephalographic sleep abnormalities in 
schizophrenia. Relationship to positive/negative symptoms and prior neuroleptic treatment. Arch Gen Psychiatry 49:185-194.

Uchimura N, Higashi H, Nishi S (1986) Hyperpolarizing and depolarizing actions of dopamine via D-1 and D-2 receptors on nucleus accumbens neurons. Brain Res 375:368-372.

Yang CR, Seamans JK (1996) Dopamine D1 receptor actions in layers V-VI rat prefrontal cortex neurons in vitro: modulation of dendriticsomatic signal integration. J Neurosci 16:1922-1935.
Young KA, Wilcox RE (1991) Characterization of D2 receptors and dopamine levels in the thalamus of the rat. Life Sci 48:1845-1852.

Young KA, Randall PK, Wilcox RE (1995) Startle and sensorimotor correlates of ventral thalamic dopamine and GABA in rodents. NeuroReport 6:2495-2499.

Zahm DS, Zaborszky L, Alheid GF, Heimer L (1987) The ventral striatopallidothalamic projection: II. The ventral pallidothalamic link. J Comp Neurol 255:592-605. 